Jurnal Tanah dan Sumberdaya Lahan Vol 8 No 1: 239-247, 2021

e-ISSN:2549-9793, doi: 10.21776/ub.jts1.2021.008.1.27

\title{
PENGARUH APLIKASI AMELIORAN DARI FORMULASI LIMBAH BATUBARA (FLY ASH DAN BOTTOM ASH) DAN SAMPAH PASAR DENGAN KAPUR TERHADAP $\mathrm{pH}$, KTK DAN P TERSEDIA ULTISOL DAN GAMBUT
}

\section{Effect of Application of Ameliorant from Formulation of Coal Waste (Fly Ash and Bottom Ash) and Market Waste with Lime on pH, CEC and Available P of Ultisols and Peat}

\author{
Farah Ilham ${ }^{1}$, Amsar Maulana ${ }^{2 *}$, Bonatua Hasiholan ${ }^{1}$, Ikhsan Ilham ${ }^{3}$, \\ Fetri Yulia Negsih ${ }^{1}$ \\ 1 Program Studi Agroekoeteknologi Fakultas Pertanian Universitas Andalas Limau Manis Padang 25175 \\ 2 Program Studi Ilmu Tanah, Fakultas Pertanian Universitas Andalas Limau Manis Padang 25175 \\ 3Program Studi Ilmu Hukum, Fakultas Hukum Universitas Andalas Limau Manis Padang 25175 \\ *Penulis korespondensi: amaulana.1005@gmail.com
}

\begin{abstract}
The formulation of coal waste (4 million $\left.\mathrm{t} \mathrm{year}^{-1}\right)$ and market waste $\left(175.000 \mathrm{t}_{\text {year }}{ }^{-1}\right)$ is a potential development of alternative ameliorant for marginal and swamplands. The purpose of this study was to examine ameliorant formulations from coal and market waste to improve $\mathrm{pH}$, available $\mathrm{P}$, and CEC of Ultisols and Peat. The step I of the study used a completely randomized design with 3 replications, namely $\mathrm{A}=$ coal waste $(100 \mathrm{~g}) ; \mathrm{B}=$ market waste $(100 \mathrm{~g}) ; \mathrm{C}=1: 1(50 \mathrm{~g}: 50 \mathrm{~g}) ; \mathrm{D}=2: 1$ $\left(66.7 \mathrm{~g} 33.3 \mathrm{~g} \mathrm{~g}^{-1}\right)$ and $\mathrm{E}=1: 2\left(33.3 \mathrm{~g} 66.7 \mathrm{~g}^{-1}\right)$. The step II of the study used a completely randomized design with 3 replications in 3 formulations namely: $\mathrm{A}=$ best formulation $(100 \mathrm{~g}) ; \mathrm{B}=$ best

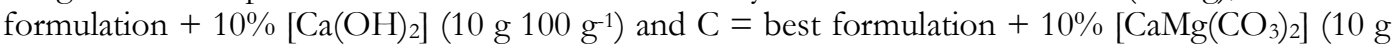
$\left.100 \mathrm{~g}^{-1}\right)$. The step III of the study used a completely randomized design with 3 replications namely: $\mathrm{A}=0 \mathrm{t} \mathrm{ha}^{-1}\left(0 \mathrm{~g} 500 \mathrm{~g}^{-1}\right.$ soil $) ; \mathrm{B}=10 \mathrm{t} \mathrm{ha}^{-1}\left(2.5 \mathrm{~g} 500 \mathrm{~g}^{-1}\right.$ soil $) ; \mathrm{C}=20 \mathrm{tha}^{-1}\left(5.0 \mathrm{~g} 500 \mathrm{~g}^{-1}\right.$ soil $) ; \mathrm{D}=$

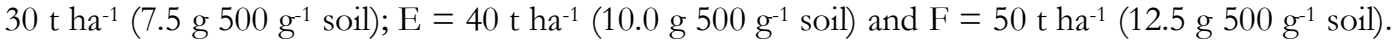
The results of the study showed that application of ameliorant formulations from coal and market waste with $10 \%\left[\mathrm{CaMg}\left(\mathrm{CO}_{3}\right)_{2}\right]$ at $50 \mathrm{t} \mathrm{ha}^{-1}$ increased $\mathrm{pH}$, available $\mathrm{P}$ and $\mathrm{CEC}$ of Ultisols and peat, respectively by 0.60 units, $2.11 \mathrm{ppm} P$ and $10.83 \mathrm{cmol}_{\mathrm{c}} \mathrm{kg}^{-1}$ on Ultisols, and 0.33 units, $2.64 \mathrm{ppm} \mathrm{P}$ and $68.86 \mathrm{cmol}_{\mathrm{c}} \mathrm{kg}^{-1}$ in peat, compared to control.
\end{abstract}

Keywords: ameliorant formulations, coal waste, lime, market waste, peat, Ultisols

\section{Pendahuluan}

Indonesia memiliki daratan seluas 188.20 juta ha, yang terdiri atas 144 juta ha lahan kering dan 44.20 juta ha lahan basah. Luas total daratan tersebut, yang sesuai untuk pertanian sekitar 94.07 juta ha. Lahan tersebut berada pada kawasan rawa seluas 7.88 juta ha, yang terdiri atas 4.06 juta ha untuk tanaman semusim dan 3.82 juta ha untuk tanaman tahunan, dengan penyebaran terluas di Sumatera dan Kalimantan.
Meskipun lahan pertanian cukup luas, namun sebagian besar lahan tersebut termasuk kedalam lahan marginal (Oxisol, Ultisol dan Inceptisol) dan juga termasuk lahan rawa (pasang surut, lebak dan Gambut) (Mulyani et al., 2020). Ultisol sebagai satu lahan marginal di Indonesia memiliki potensi besar yang dapat dikembangkan sebagai lahan pertanian berkelanjutan, namun memiliki kesuburan yang rendah. Ultisol di Indonesia yang mempunyai 


\section{Jurnal Tanah dan Sumberdaya Lahan Vol 8 No 1: 239-247, 2021 e-ISSN:2549-9793, doi: 10.21776/ub.jts1.2021.008.1.27}

sebaran luas mencapai 45.794 .000 ha atau sekitar $25 \%$ dari total luas daratan Indonesia. Sebaran terluas terdapat di Kalimantan (21.938.000 ha), diikuti di Sumatera (9.469.000 ha), Maluku dan Papua (8.859.000 ha), Sulawesi (4.303.000 ha), Jawa (1.172.000 ha), dan Nusa Tenggara (53.000 ha) (Syahputra et al., 2015). Karakteristik Ultisol yang sering menjadi masalah yaitu keasaman tanah, bahan organik rendah dan nutrisi makro rendah dan memiliki ketersediaan P sangat rendah (Fitriatin et al., 2014; Syahputra et al., 2015). Mulyani et al. (2020) menyatakan bahwa kapasitas tukar kation (KTK), kejenuhan basa (KB) dan C-organik rendah, kandungan aluminium (kejenuhan $\mathrm{Al}$ ) tinggi, fiksasi $\mathrm{P}$ tinggi, kandungan besi dan mangan mendekati batas meracuni tanaman, peka akan erosi (Syahputra et al., 2015). Hal ini juga terjadi kendala dalam pemanfaatan lahan rawa sebagai lahan pertanian seperti Gambut,

Luas lahan gambut di Indonesia memiliki luas 14.95 juta hektar tersebar di Pulau Sumatera, Kalimantan, dan Papua serta sebagian kecil di Sulawesi. Sekitar 5.241.473 ha atau $35.17 \%$ dari total luas lahan gambut Indonesia tergolong gambut dangkal, tersebar di Pulau Papua (2.425.523 ha), Pulau Sumatera (1.767.303 ha), dan Pulau Kalimantan (1.048.611 ha). Lahan gambut dengan ketebalan $50-100 \mathrm{~cm}$ tergolong lahan gambut dangkal/tipis. Karakteristik tanah gambut sangat berbeda dengan tanah mineral (Masganti et al., 2020), berkaitan dengan sifat kimia, fisika, dan biologi. Karakteristik gambut dapat berubah akibat adanya tindakan manusia berupa pembukaan lahan, pembakaran lahan, pembuatan saluran drainase, dan penambangan (Page et al., 2002; Hirano et al., 2007; Masganti et al., 2020). Sifat kimia gambut yang menonjol dan berkaitan dengan pertanian meliputi kemasaman tanah, cadangan karbon, ketersediaan hara, KTK, kadar abu, asam organik, dan pirit, dan jenis stratum yang berada di bawah lapisan gambut (Dimitriu et al., 2010; Melling et al., 2013; Fahmi et al., 2014; Masganti et al., 2020).

Tingkat kemasaman tanah menjadi faktor pembatas dalam pengembangan gambut untuk tujuan pertanian. Berbagai hasil penelitian menunjukkan bahwa tingkat kemasaman tanah gambut tergolong sangat masam (Masganti et al., 2020). Kemasaman tanah gambut disebabkan adanya hidrolisis asam-asam organik dan kondisi drainase yang jelek. Dengan demikian, perlunya sebuah teknologi yang bersifat ekonomis untuk memperbaiki permasalahan yang ada pada lahan pertanian (Ultisol dan Gambut) melalui pemanfaatkan limbah industri dan organik yang ada di tengah - tengah masyarakat seperti limbah batubara dan sampah pasar.

Potensi limbah industri dari limbah batubara mencapai lebih kurang $4-5$ juta $\mathrm{t}$ tahun $^{-1}$. Fly ash dan Bottom Ash merupakan limbah padat yang dihasilkan dari pembakaran batubara pada pembangkit tenaga listrik. Sebaran fly ash dan bottom ash dipengaruhi oleh gaya gravitasi bumi. Jumlah limbah abu batubara yang sangat besar apabila tidak dikelola dan dimanfaatkan dengan benar dapat menimbulkan masalah lingkungan yang serius selain memerlukan tempat penampungan yang sangat luas (Kinasti dan Notodisuryo, 2017). Berdasarkan UU No. 32 Tahun 2009, penggolongan Fly ash dan bottom ash sebagai limbah B3 (Peraturan Pemerintah Nomor 101 Tahun 2014 tentang Pengelolaan Limbah B3) membuat fly ash dan bottom ash harus mendapatkan perlakuan kusus dalam pengelolaannya. Pemahaman yang baik tentang pengelolaan limbah B3 akan mengerucut pada sebuah kesimpulan bahwa pilihan penimbunan sehingga perlu dilakukan kegiatan pemanfaatan sebagai alternatif sebelum landfill melalui teknologi formulasi dengan bahan organik alternative seperti sampah pasar.

Sampah pasar di Indonesia mencapai $175.000 \mathrm{t}^{\mathrm{tahun}}{ }^{-1}$ pengelolaan sampah yang dilakukan yaitu dengan diangkut dan ditimbun di Tempat Pemprosesan Akhir (TPA) sampah sebanyak $69 \%$, dikubur sebanyak $10 \%$, dikompos dan didaur ulang sebanyak $7 \%$, dibakar sebanyak 5\% dan sisanya tidak terkelola sebanyak 7\% (Nirmala et al., 2020). Sampah yang tidak ditangani dengan baik akan menjadi sumber penyakit, sumber pencemar yang menghasilkan leachate yang dapat mencemari air tanah, dan gas yang mengandung metan sehingga dapat mencemari udara dan menjadi salah satu penyebab pemanasan global, serta dapat menimbulkan bau busuk. Pengolahan sampah sangat diperlukan, khususnya sampah pasar yang mendominasi tingginya timbulan sampah organik di Indonesia dapat digunakan sebagai pupuk hijau dan kompos di bidang 


\section{Jurnal Tanah dan Sumberdaya Lahan Vol 8 No 1: 239-247, 2021}

e-ISSN:2549-9793, doi: 10.21776/ub.jts1.2021.008.1.27

pertanian (Gabler, 2014; (Nirmala et al., 2020).). Maka, dari potensi yang terdapat pada limbah industri seperti limbah batubara dan limbah organik dari sampah pasar dapat dijadikan sebuah formulasi ameliorant yang dapat memperbaiki lahan marginal dan lahan rawa di Indonesia. Tujuan dari penelitian ini adalah mengkaji pengaruh formulasi ameliorant dari limbah batubara dan sampah kota dalam memperbaiki sifat kimia $(\mathrm{pH}, \mathrm{P}$ tersedia dan KTK) Ultisol dan Gambut.

\section{Bahan dan Metode}

\section{Waktu dan tempat}

Penelitian ini telah dilakukan di Laboratorium Kimia dan Kesuburan Tanah Fakultas Pertanian, Universitas Andalas, Padang, mulai dari Mei hingga Oktober 2020.

\section{Persiapan limbah batubara, sampah pasar, kapur dan sampel tanah}

Ultisol dan Gambut yang digunakan untuk percobaan ini diambil secara komposit pada kedalaman $0-20 \mathrm{~cm}$ dari permukaan tanah di Kebun Percobaan, Fakultas Pertanian, Universitas Andalas, Limau Manis Padang dan Daerah Ketaping, Kec. Batang Anai, Kab. Padang Pariaman, Sumatera Barat. Kemudian sampel tanah dikeringkan anginkan, dihaluskan lalu diayak dengan ayakan $2 \mathrm{~mm}$ dan diaduk sampai homogen. Kadar air tanah ditentukan, kemudian sampel yang diayak dimasukkan ke dalam pot yang masing-masing setara dengan $500 \mathrm{~g}$ berat kering mutlak. Jenis limbah batubara yang digunakan dalam bentuk fly ash dan bottom ash dari limbah batubara yang diambil dari Electrostatic Presipitator (ESP) dari PLTU Ombilin, Sawahlunto. Sampah pasar yang digunakan dari kumpulan sampah pasar di Kota Padang, Sumatera Barat dari jenis organik (sampah sayuran, buah - buahan). Semua sampah tersebut diblender hingga halus dan dicampurkan (tanpa memperhitungkan kadar air sampah) kedalam rasio yang telah ditetapkan dalam penelitian. Jenis kapur yang digunakan terdiri atas kapur hidrat $\left[\mathrm{Ca}(\mathrm{OH})_{2}\right]$; dan dolomit $\left[\mathrm{CaMg}\left(\mathrm{CO}_{3}\right)_{2}\right]$. Kapur yang digunakan merupakan produk perusahaan swasta di Indonesia, di mana deskripsi masing-masing jenis kapur adalah sebagai berikut: (1)) kapur hidrat pada 325 mesh dengan $95 \% \mathrm{Ca}(\mathrm{OH})_{2}$ konten dan 1\% kadar air (PT. Niraku Jaya Abadi) dan (2) Dolomit pada 325 mesh dengan $21 \%$ konten $\mathrm{MgO}$ dan $30 \% \mathrm{CaO}$; dengan $\mathrm{pH}>$ 9,5 unit dan proporsi $2.66-2.75 \mathrm{~g} \mathrm{~cm}^{-3}$ dan kadar air $0.1-0.5 \%$ (CV. Libra Mandiri Pratama).

\section{Pelaksanaan penelitian dan analisis amelioran dan tanah}

Penelitian ini terdiri atas 3 tahap penelitian yaitu tahap I bertujuan untuk mengkaji karakteristik kimia formulasi dari limbah batubara dan sampah pasar menggunakan Rancangan Acak Lengkap dengan 3 ulangan. Formulasi terdiri atas 5 formulasi sebagai berikut: $\mathrm{A}=$ limbah batubara (100g); B = sampah pasar (100g); C = rasio formulasi $1: 1$ (50g limbah batubara : $50 \mathrm{~g}$ sampah pasar); $\mathrm{D}=$ rasio formulasi $2: 1$ (66.7g limbah batubara : $33.3 \mathrm{~g}$ sampah pasar) dan $\mathrm{E}=$ rasio formulasi 1 : 2 (33.3g limbah Batubara : 66.7g sampah pasar).

Penelitian tahap II bertujuan untuk mengkaji karakteristik kimia formulasi terpilih dari tahap I yang dikombinasi dengan kapur. Penelitian tahap II mengunakan Rancangan Acak Lengkap dengan 3 ulangan pada 3 formulasi sebagai berikut: $\mathrm{A}=$ formulasi terpilih $(100 \mathrm{~g}) ; \mathrm{B}=$ formulasi terpilih dengan $10 \%$ kapur hidrat $\left[\mathrm{Ca}(\mathrm{OH})_{2}\right]\left(\begin{array}{llll}10 & \mathrm{~g} & 100 \mathrm{~g}^{-1}\end{array}\right)$ dan $\mathrm{C}=$ formulasi terpilih dengan 10\% kapur dolomit

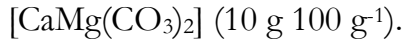

Penelitian tahap III bertujuan untuk mengkaji pengaruh dosis formulasi terbaik dari penelitian tahap II terhadap $\mathrm{pH}$, KTK dan P tersedia Ultisol dan Gambut. Dosis terdiri atas 6 taraf perlakuan menggunakan Rancangan Acak Lengkap dengan 3 ulangan sebagai berikut: $A=$ $0 \mathrm{t} \mathrm{ha}^{-1}$ (0 g $500 \mathrm{~g}^{-1}$ tanah); B $=10 \mathrm{tha}^{-1}(2.5 \mathrm{~g}$ $500 \mathrm{~g}^{-1}$ tanah); C $=20 \mathrm{t} \mathrm{ha}^{-1}$ (5.0 g $500 \mathrm{~g}^{-1}$ tanah); $\mathrm{D}=30 \mathrm{t} \mathrm{ha}^{-1}\left(7.5 \mathrm{~g} / 500 \mathrm{~g}\right.$ tanah); $\mathrm{E}=40 \mathrm{tha}^{-1}$

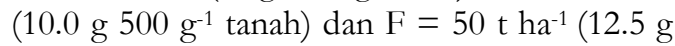
$500 \mathrm{~g}^{-1}$ tanah).

Berdasarkan ketiga langkah penelitian ini setiap perlakuan dihomogenkan sesuai dengan takaran dan campuran yang telah ditetapkan sesuai perlakuan. Kemudian ditambahkan dengan $\mathrm{H}_{2} \mathrm{O}$ sampai berada pada keadaan kapasitas lapang dan dinkubasi selama 1 × 24 jam didalam gelas piala $250 \mathrm{ml}$ yang ditutup dengan plastik hitam secara keseluruhan. Selanjutnya dilanjutkan ke masing-masing 
analisis terhadap karakteristik ameliorant (tahap I dan II) dan tanah (tahap III). Analisis ameliorant berupa $\mathrm{pH} \quad \mathrm{H}_{2} \mathrm{O}$ (1:1) dengan metode Elektrometri, KTK dengan metode pencucian $\mathrm{NH}_{4} \mathrm{OAc} 1 \mathrm{~N}$ pH 7 (Balai Penelitian Tanah, 2012). Analisis tanah berupa $\mathrm{pH} \mathrm{H} \mathrm{H}_{2} \mathrm{O}$ (1:2 pada Ultisol) dan (1:5 pada Gambut) dengan metode Elektrometri, KTK dengan metode pencucian $\mathrm{NH}_{4} \mathrm{OAc} 1 \mathrm{~N}$ pH 7 dan Ptersedia dengan metode Bray II, (Balai Penelitian Tanah, 2012).

\section{Analisis statistik}

Hasil penelitian dilakukan analisis statistik menggunakan Software Statistix 8 dan Microsoft Exel 2016, dalam menganalisis formulasi dan perubahan $\mathrm{pH}$, KTK dan $\mathrm{P}$ tersedia Ultisol dan Gambut. Data dianalisis secara statistik dengan uji $\mathrm{F}$ analisis varians (ANOVA), jika pengobatan $\mathrm{F}$ hitung $>\mathrm{F}$ table, maka $5 \%\left(^{*}\right)$ dan $1 \%(* *)$.

\section{Hasil dan Pembahasan}

\section{Karakteristik kimia amelioran dari formulasi limbah batubara dan sampah pasar}

Pada Gambar 1 terlihat karakteristik kimia amelioran dari formulasi limbah batubara dan sampah kota berpengaruh nyata terhadap $\mathrm{pH}$ dan KTK amelioran. Kandungan $\mathrm{pH}$ tertinggi pada limbah batubara sebesar 7.53 unit dan formulasi rasio (2:1) limbah batubara dan sampah kota sebesar 6.17 unit, sedangkan pH terendah pada sampah kota sebesar 4.50 unit dan formulasi rasio (1:2) limbah batubara dan sampah kota sebesar 5.73 unit (Gambar 1A). Hal ini disebabkan komposisi limbah batubara terdiri atas beberapa oksida seperti SiO, sedangkan sampah pasar didominasi oleh asam organik. Menurut Hermawan et al. (2014), limbah terbang batu bara dapat digunakan sebagai bahan penetral $\mathrm{pH}$ tanah dan sangat berpotensi untuk mengurangi pemakaian kapur guna menurunkan tingkat kemasaman tanah, disebabkan karakteristik mineralogi limbah batubara lebih kompleks dibanding bahan kapur, dimana reaksi netralisasinya juga melibatkan mineral lain seperti $\mathrm{Ca}, \mathrm{Mg}$ silikat dan aluminosilikat. Kemasaman sampah kota disebabkan $85-95 \%$ berasal dari gugus karboksil dan fenol (Yondra dan Nelvia, 2017).

KTK tertinggi pada sampah kota sebesar $70.00 \mathrm{cmol}_{\mathrm{c}} \mathrm{kg}^{-1}$ dan formulasi rasio (1:2) limbah batubara dan sampah kota sebesar $67.00 \mathrm{cmol}_{\mathrm{c}}$ $\mathrm{kg}^{-1}$, sedangkan KTK terendah pada limbah batubara sebesar $11.20 \mathrm{cmol}_{\mathrm{c}} \mathrm{kg}^{-1}$ dan formulasi rasio (2:1) limbah batubara dan sampah kota sebesar $12.20 \quad \mathrm{cmol}_{\mathrm{c}} \quad \mathrm{kg}^{-1}$ (Gambar 1B). Tingginya KTK sampah pasar berasal penyusun bahan organik yang berupa fraksi hemiselulosa, selulosa dan lignin dan senyawa humat (Yondra dan Nelvia, 2017). Menurut Noviardi, (2013) kapasitas tukar kation (KTK) pada limbah batubara termasuk kriteria sedang yaitu sebesar $20,74 \mathrm{cmol}_{\mathrm{c}} \mathrm{kg}^{-1}$.

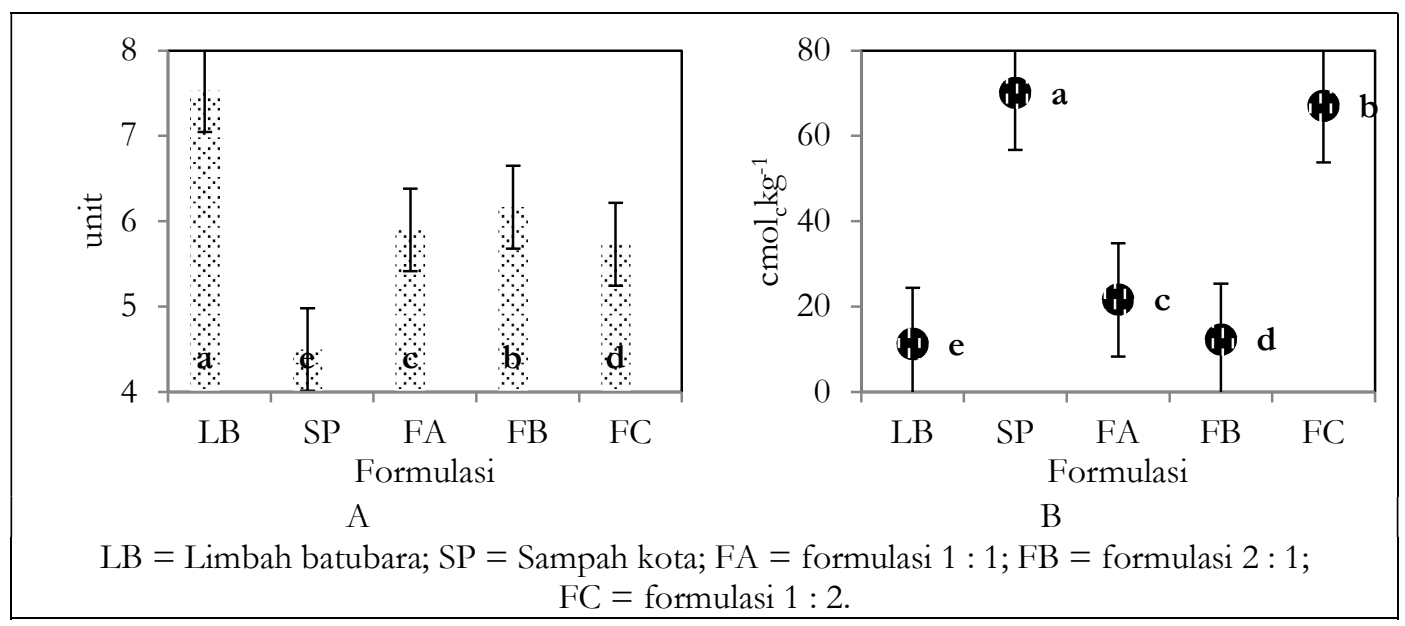

Gambar 1. Karakteristiki pH (A) dan KTK (B) dari formulasi amelioran (limbah batubara dan sampah kota). 


\section{Jurnal Tanah dan Sumberdaya Lahan Vol 8 No 1: 239-247, 2021 e-ISSN:2549-9793, doi: 10.21776/ub.jts1.2021.008.1.27}

Berdasarkan karakteristik kimia amelioran dari formulasi limbah batubara dan sampah pasar dari penelitian tahap I ini, maka formulasi rasio (2:1) yang akan digunakan sebagai formulasi terpilih untuk dilanjutkan untuk penelitian tahap II. Hal ini disebabkan kandungan $\mathrm{pH}$ (6.17 unit) dan KTK (12.20 $\left.\mathrm{cmol}_{\mathrm{c}} \mathrm{kg}^{-1}\right)$, dibandingkan bahan baku yang digunakan. Menurut Nawaz (2013); Kurniawan et al. (2014) bahwa limbah batubara juga bisa berfungsi sebagai ameliorant dan insektisida jika digunakan bersama dengan limbah organik (bio-waste), bahkan mampu mengurangi penggunaan pupuk kimia dalam jumlah yang signifikan.

\section{Karakteristik kimia amelioran dari formulasi dengan kapur}

Karakteristik kimia amelioran dari formulasi dengan kapur berpengaruh nyata terhadap $\mathrm{pH}$ dan KTK amelioran (Gambar 2). Berdasarkan pengaruh pemberian $10 \%$ kapur hidrat dapat meningkatan $\mathrm{pH}$ sebesar 6.06 unit, sedangkan $10 \%$ dolomit sebesar 2.13 unit, dibandingkan formulasi terpilih. Hal ini disebabkan kapur hidrat dan dolomit memiliki nilai $\mathrm{pH}$ yang tinggi.
Menurut Noviardi, (2013) limbah batubara memiliki $\mathrm{pH}$ alkalin, unsur hara baik makro maupun mikro, dan ukuran yang halus. Hal ini menyebabkan limbah batubara dapat dimanfaatkan untuk meningkatkan $\mathrm{pH}$, menambah kandungan unsur hara, meningkatkan struktur dan kapasitas kelembaban.

Pada Gambar 2B juga terlihat kandungan KTK tertinggi pada pemberian 10\% kapur dolomit sebesar $3.34 \mathrm{cmol}_{\mathrm{c}} \mathrm{kg}^{-1}$. Namun, dengan pemberian $10 \%$ hidrat terjadi penuruan kandungan KTK sebesar $5.40 \mathrm{cmol}_{\mathrm{c}} \mathrm{kg}^{-1}$, sedangkan kandungan KTK formulasi terpilih memiliki nilai sebesar $12.20 \quad \mathrm{cmol}_{\mathrm{c}} \mathrm{kg}^{-1}$. Berdasarkan karakteristik kimia amelioran dari formulasi dengan kapur bahwa pemberian 10\% kapur dolomit menjadi formulasi terbaik untuk dijadikan sebagai amelioran alternatif yang bersifat ekonomis yang dikembangkan secara berkelanjutan. Menurut Abfertiawan et al. (2012) pemnfaatan kapur yang dimasukkan pada limbah batubara dan limbah organik dapat diformulasikan secara aktif dan pasif sebagai ameliorant tanah dan insektisda alami.

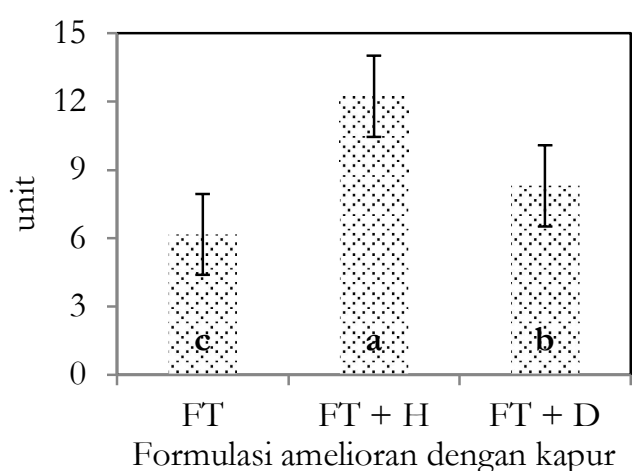

A

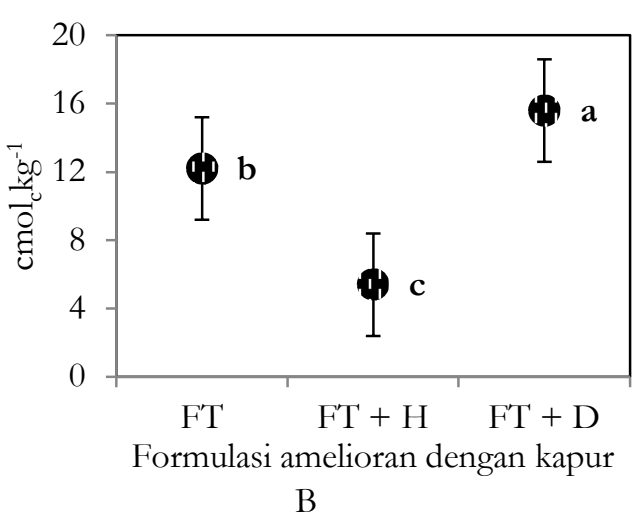

B

$\mathrm{FT}=$ Formulasi terpilih (formulasi $2: 1$ ); $\mathrm{FT}+\mathrm{H}=$ formulasi $2: 1$ dengan kapur hidrat dan $\mathrm{FT}+\mathrm{D}=$ formulasi $2: 1$ dengan kapur dolomit

Gambar 2. Karakteristiki pH (A) dan KTK (B) dari formulasi amelioran (limbah batubara dan sampah kota).

\section{Karakteristik Fluoresensi sinar-X (XRF)}

Pada Gambar 3 terlihat hasil karaktersitik Fluoresensi sinar- $X(\mathrm{XRF})$ dari formulasi limbah batubara dengan sampah kota menunjukkan bahwa komposisi elemen dari limbah batubara dengan sampah kota berbeda. Pada Gambar 1 terlihat bahwa $\mathrm{pH}$ limbah batubara bersifat basa (7.53 unit), sedangkan sampah kota bersifat asam (4.50 unit). Hal ini sesuai dengan hasil

XRF bahwa limbah batubara memiliki 
komposisi sebesar $52.98 \% \mathrm{Si} ; 27.21 \% \mathrm{Al} ; 7.91 \%$ Fe; $4.81 \% \mathrm{~K}$ dan $2.06 \%$ Ca sedangan sampah kota yaitu $41.89 \% \mathrm{Ca}, 36.62 \% \mathrm{~K}$; $5.34 \% \mathrm{P}$; $5.29 \% \mathrm{~S}$ dan $4.05 \% \mathrm{Cl}$. Hal ini diduga bahan baku limbah batubara yang digunakan dalam industri pertambangan dari jenis batubara peringkat tinggi dan juga hasil proses gasifikasi batubara.

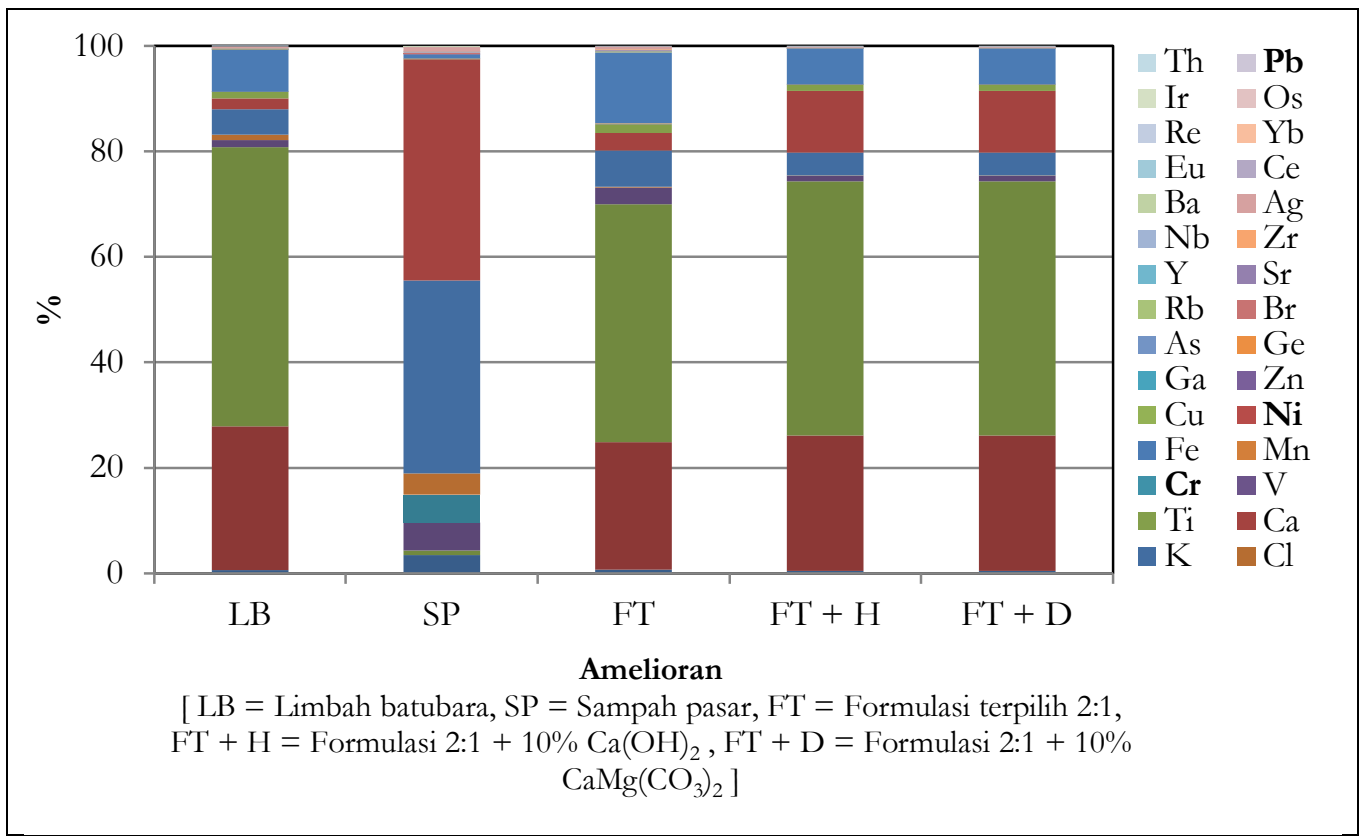

Gambar 3. Karakteristik Fluoresensi sinar-X (XRF) dari formulasi limbah batubara dengan sampah kota.

Berdasarkan Kurniawan et al. (2014) bahwa 9599\% abu terbang batu bara terdiri atas oksida $\mathrm{Si}$, $\mathrm{Al}, \mathrm{Fe}, \mathrm{Ca}$, dan $\mathrm{Mg}$. Berdasarkan kandungan senyawa $\mathrm{CaO}$ yang diperoleh abu terbang batu bara yang digunakan dalam penilitian ini tergolong kelas $\mathrm{F}$ yaitu merupakan hasil pembakaran batu bara jenis anthracite atau bitumen, hal ini karena kandungan $\mathrm{CaO}$ pada abu terbang batu bara yang digunakan ini adalah $<10 \%$. Dari hasil analisis ini dapat disimpulkan bahwa kandungan sifat kimia abu terbang batu bara tergantung pada kualitas kelas batu bara yang digunakan dan kondisi di Thermal Power Station (TPS). Kandungan hara total P (0,03\%) dan $\mathrm{K}(0,05 \%)$ dikategorikan dalam kriteria rendah. Hasil formulasi amelioran dari limbah batubara dan sampah kota terpilih pada rasio 2:1 terlihat komposisi didominasi oleh $45.05 \% \mathrm{Si}$; $24.25 \% \mathrm{Al} ; 13.32 \% \mathrm{Fe}$; $6.91 \% \mathrm{~K}$; $3.22 \% \mathrm{P}$ dan $3.22 \%$ Ca. Peubahan komposisi dari formulasi terpilih dapat memunculkan hara tambahan yang dibutuhkan oleh tanaman yang akan dijadikan sebagai amelioran tanah. Hal ini diduga dari hara yang disumbangkan oleh sampah kota terhadap limbah batubara sehingga hara didalam formulasi meningkat.

Pada Gambar 3 juga terlihat perubahan komposisi dari formulasi amelioran dari limbah batubara dan sampah kota terbaik dengan pemberian kapur dalam menguarangi kandungan logam dari limbah batubara dan sampah kota. Formulasi terpilih (2:1) dengan $10 \%$ hidrat dan dolomit meiliki komposisi yang lebih tinggi, dibandingakn dengan formulasi terpilih (2:1). Hal yang paling terlihat dari pemberian kapur ini adalah terjadinya penurunan kandungan logam berat $(0.035 \% \mathrm{Cr}$, $0.011 \% \mathrm{~Pb}$, dan $0.021 \% \mathrm{Ni})$ dari limbah batubara dan sampah kota sebesar $0.70 \% \mathrm{Cr}$; $1.70 \% \mathrm{~Pb} ; 2.90 \% \mathrm{Ni}$. Hal ini diduga karena ion $\mathrm{OH}$ yang disumbangkan dari kapur yang dapat menjerap logam berat dalam formulasi amelioran dari limbah batubara dan sampah kota. Menurut Oktafiansyah et al. (2020) bahwa kapur merupakan salah satu bahan baku atau batuan yang dapat dipergunakan untuk 


\section{Jurnal Tanah dan Sumberdaya Lahan Vol 8 No 1: 239-247, 2021 e-ISSN:2549-9793, doi: 10.21776/ub.jts1.2021.008.1.27}

meningkatkan $\mathrm{pH}$ secara praktis, murah dan aman sekaligus dapat mengurangi kandungankandungan logam berat pada limbah industri seperti kapur kalsit $\left(\mathrm{CaCO}_{3}\right)$, kapur tohor $(\mathrm{CaO})$, kapur hidrat $\left[\mathrm{Ca}(\mathrm{OH})_{2}\right]$, dolomit $\left[\mathrm{CaMg}\left(\mathrm{CO}_{3}\right)_{2}\right]$ dan kapur silika $\left(\mathrm{CaSiO}_{3}\right)$.

\section{Karakteristik pH, KTK dan P tersedia Ultisol dan gambut}

Pada Gambar 4 terlihat hasil analisis sidik ragam $\mathrm{pH}$ tanah setelah inkubasi memperlihatkan bahwa formulasi ameliorant dari limbah batubara dan limbah sampah berpengaruh sangat nyata terhadap peningkatan $\mathrm{pH}$ Ultisol dan Gambut. Peningkatan pH Ultisol terbaik terjadi pada pemberian formulasi ameliroan pada dosis $50 \mathrm{t} \mathrm{ha}^{-1}$ dapat meningkatkan $\mathrm{pH}$ sebesar 0.60 unit (Gambar 4A), sedangkan pada Gambut sebesar 0.33 unit (Gambar 4B), dibandingkan dengan kontrol. Pemberian formulasi amelioran dosis 30 dan $40 \mathrm{t} \mathrm{ha}^{-1}$ memperlihat pengaruh yang sama terhadap peningkatan $\mathrm{pH}$ Ultisol dan Gambut masing masing sebesar 5.13; 5.13 unit pada Ultisol dan
4.43; 4.43 unit pada Gambut. Pada Gambar 4 juga terlihat pemberian formulasi ameliorant 50 $\mathrm{t} \mathrm{ha}^{-1}$ berbeda nyata dengan kontrol dan pemberian formulasi ameliorant $10,20 \mathrm{t} \mathrm{ha}^{-1}$ terhadap peningkatan $\mathrm{pH}$ Ultisol dan Gambut. $\mathrm{Hal}$ ini diduga dari pengaruh $\mathrm{pH}$ formulasi ameliorant dengan $10 \%$ dolomit sebesar 8.30 unit (alkalis).

Penambahan limbah batubara pada tanah dapat meningkatkan $\mathrm{pH}$, terutama pada tanah masam daripada tanah yang cenderung basa sehingga $\mathrm{pH}$ tanah cenderung menjadi netral (Noviardi, 2013). Menurut Priatmadi et al. (2012) peningkatan $\mathrm{pH}$ tanah pada tanah dari pengaruh limbah batubara dapat meningkatkan muatan negatif tanah melalui mekanisme deprotonisasi ion $\mathrm{H}^{+}$pada mineral liat. Terjadinya deprotonisasi ion $\mathrm{H}^{+}$ini diindikasikan dengan terjadinya peningkatan $\mathrm{pH}$ tanah dengan penambahan limbah batubara. Pemberian formulasi ameliorant dari limbah batubara dan limbah sampah berpengaruh sangat nyata terhadap peningkatan $\mathrm{P}$ tersedia Ultisol dan Gambut.

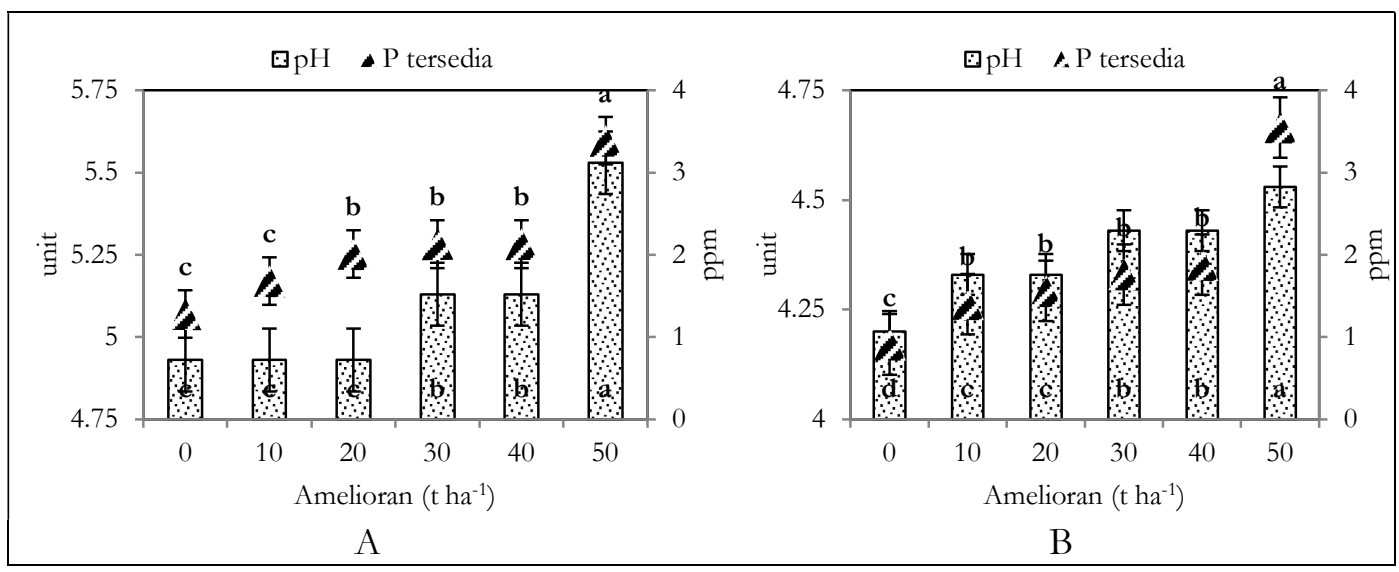

Gambar 4. Pengaruh dosis amelioran dari formulasi limbah batubara dan sampah kota dengan 10\% dolomit terhadap $\mathrm{pH}, \mathrm{P}$ tersedia Ultisol (A) dan Gambut (B).

Peningkatan $\mathrm{P}$ tersedia terbaik pada pemberian formulasi ameliorant $50 \mathrm{t} \mathrm{ha}^{-1}$ masing - masing sebesar 2.11 ppm P Ultisol (Gambar 4A) dan 2.64 ppm P Gambut (Gambar 4B), dibandingkan dengan kontrol. Pemberian formulasi ameliorant 20, 30 dan $40 \mathrm{t} \mathrm{ha}^{-1}$ terlihat sama dalam meningkatkan P tersedia Ultisol, sedangkan pada Gambut pemberian formulasi 10, 20, 30 dan $40 \mathrm{t} \mathrm{ha}^{-1}$ terlihat sama dalam meningkatkan $\mathrm{P}$ tersedia. Pemberian formulasi $50 \mathrm{t} \mathrm{ha}^{-1}$ berbeda nyata dengan kontrol dan pemberian formulasi ameliorant $10 \mathrm{t} \mathrm{ha}^{-1}$ pada Ultisol, sedangkan berbeda nyata dengan control pada Gambut. Hal ini disebabkan peningkatan $\mathrm{P}$ tersedia dipengaruhi oleh peningkatan $\mathrm{pH}$ tanah. Menurut Hermawan et al. (2014) menyatakan bahwa, hidrolisis senyawa oksida seperti $\mathrm{CaO}, \mathrm{MgO}, \mathrm{Na}_{2} \mathrm{O}$, dan $\mathrm{K}_{2} \mathrm{O}$ pada 


\section{Jurnal Tanah dan Sumberdaya Lahan Vol 8 No 1: 239-247, 2021}

e-ISSN:2549-9793, doi: 10.21776/ub.jts1.2021.008.1.27

limbah batubara akan menghasilkan muatan negatif yang dapat menetralisir muatan positif pada permukaan koloid tanah sehingga jerapan P tanah menjadi berkurang. Pada Gambar 5 terlihat hasil analisis sidik ragam KTK tanah setelah inkubasi memperlihatkan bahwa formulasi ameliorant dari limbah batubara dan limbah sampah berpengaruh sangat nyata terhadap peningkatan KTK Ultisol dan Gambut.

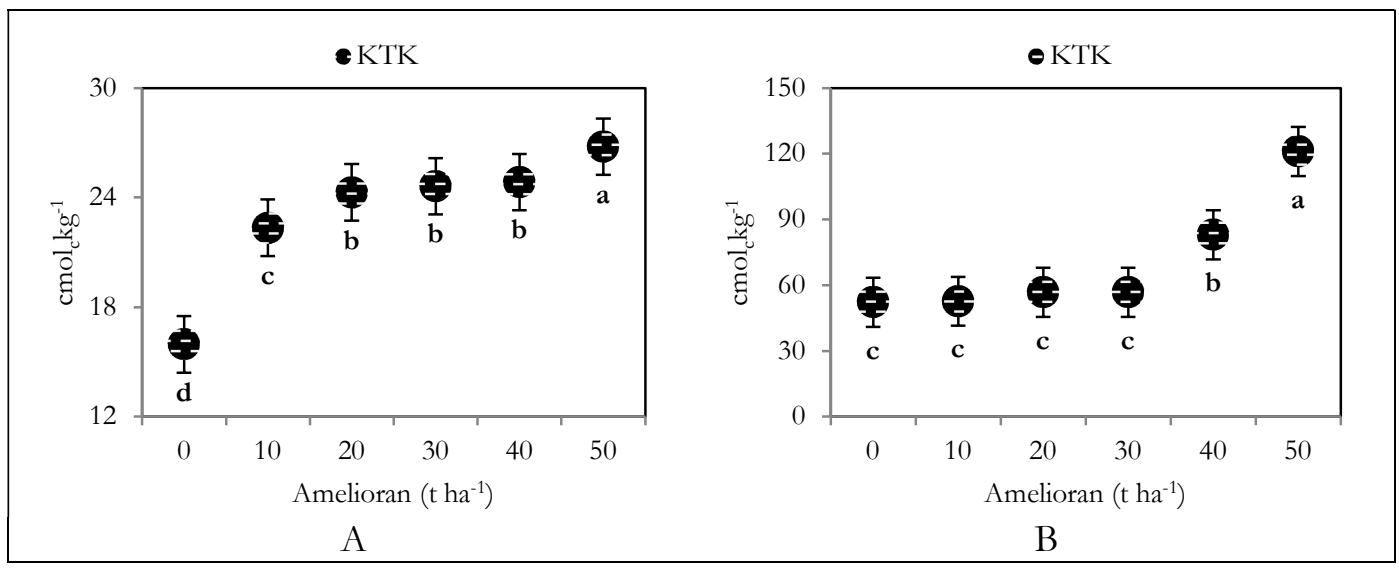

Gambar 5. Pengaruh dosis amelioran dari formulasi limbah batubara dan sampah kota dengan 10\% dolomit terhadap K'TK Ultisol (A) dan Gambut (B).

Pemberian amelioran $50 \mathrm{t} \mathrm{ha}^{-1}$ memberikan pengaruh yang berbeda nyata terhadap KTK Ultisol sebesar $10.83 \mathrm{cmol}_{\mathrm{c}} \mathrm{kg}^{-1}$ (Gambar 5A), sedangkan pada gambut $68.86 \mathrm{cmol}_{\mathrm{c}} \mathrm{kg}^{-1}$ (Gambar 5B), dibandingkan kontrol. Hal ini karena muatan negatif di dalam tanah semakin tinggi dari KTK formulasi ameliorant limbah batubara dan sampah kota. Pemberian formulasi ameliorant $10 \mathrm{t} \mathrm{ha}^{-1}$ dapat secara langsung meningkatan KTK Ultisol sebesar 6.38 cmol $_{\mathrm{c}}$ $\mathrm{kg}^{-1}$, dibandingkan dengan kontrol dan terus meningkat seiring dengan peningkatan dosis formulasi ameliorant yang diberikan kedalam tanah (Gambar 5A). Pada Gambar 5B terlihat bahwa peningkatan KTK Gambut terjadi pada pemberian formulasi ameliorant $40 \mathrm{t} \mathrm{ha}^{-1}$ sebesar $30.78 \mathrm{cmol}_{\mathrm{c}} \mathrm{kg}^{-1}$, dibandingkan dengan kontrol dan meningkat dengan pemberian $50 \mathrm{t}$ $\mathrm{ha}^{-1}$. Peningkatan nilai KTK seiring peningkatan nilai $\mathrm{pH}$ tanah menyebabkan terjadinya disosiasi ion $\mathrm{H}^{+}$dari asam-asam organik yang menghasilkan muatan negatif, dengan meningkatnya muatan negatif maka nilai KTK akan meningkat (Oktaviana dan Nelvia, 2012). KTK tanah dipengaruhi oleh sifat dan unsur tanah itu sendiri antara lain $\mathrm{pH}$, tekstur tanah, jenis mineral tanah, bahan unsur serta pengapuran dan pemupukan (Noviardi, 2013).

\section{Kesimpulan}

Pemberian 10\% dolomit dalam formulasi limbah batubara (fly ash dan bottom ash) dan sampah pasar dapat menurunan konsentrasi $\mathrm{Cr}$, $\mathrm{Pb}$ dan $\mathrm{Ni}$, masing- masing sebesar $0.70 \%$; $1.70 \%$ dan $2.90 \%$. Pemberian $50 \mathrm{t} \mathrm{ha}^{-1}$ amelioran dari formulasi limbah batubara (fly ash dan bottom ash) dan sampah pasar dengan 10\% dolomit dapat meningkatan $\mathrm{pH}, \mathrm{P}$ tersedia dan KTK Ultisol dan Gambut, masing-masing 0.60 unit, 2.11 ppm P dan $10.83 \mathrm{cmol} \mathrm{kg}^{-1}$ pada Ultisol dan 0.33 unit, 2.64 ppm $\mathrm{P}$ dan 68.86 cmol kg-1 pada Gambut, dibandingkan dengan kontrol.

\section{Ucapan Terima Kasih}

Penulis mengucapkan terima kasih kepada Tim Project 2020 yang telah berkontribusi selama kegiatan penelitian.

\section{Daftar Pustaka}

Abfertiawan, M.S., Gunawan, F., Vince, R.I. dan Gautama, R.S. 2012. Rancangan Pengelolaan Air Asam Tambang di Area Timbunan Qo3 Site Lati. Seminar Air Asam Tambang di Indonesia ke-4. Bandung, 7-8 Februari 2012 


\section{Jurnal Tanah dan Sumberdaya Lahan Vol 8 No 1: 239-247, 2021 e-ISSN:2549-9793, doi: 10.21776/ub.jts1.2021.008.1.27}

Balai Penelitian Tanah. 2012. Analisis Kimia Tanah, Air, Tanaman dan Pupuk. Balai Penelitian Tanah. Bogor. 246p.

Dimitriu, P.A., Lee, D. and Grayston, S.J. 2010. An evaluation of the functional significance of peat microorganisms using a reciprocal transplant approach. Soil Biology and Biochemistry 42:6571.

Fahmi, A., Radjagukguk, B. dan B.H. Purwanto. 2014. Interaction of peat soil and sulphidic material substratum: role of peat layer and groundwater level fluctuations on phosphorus concentration. Journal of Tropical Soils 19(3):161-169.

Fitriatin, B.N., Yuniarti, A. Turmuktini, T. and Ruswandi, F.K. 2014. The effect of phosphate solubilizing microbe producing growth regulators on soil phosphate, growth and yield of maize and fertilizer efficiency on Ultisol. Eurasian Journal of Soil Science 3:101-107.

Gabler F. 2014. Using black soldier fly for waste recycling and effective Salmonella spp. reduction [theses]. Swedish (SE): University of Agricultural Sciences.

Hermawan, A., Sabaruddin, Marsi, Hayati, R. dan Warsito. 2014. Perubahan Jerapan P Pada Ultisol Akibat Pemberian Abu Terbang Batu BaraKotoran Ayam. Palembang: Fakultas Pertanian Universitas Sriwijaya.

Hirano, T., Segah, H., Harada, T., Limin, S., June, T., Hirata, R. and Osaki. M 2007. Carbon dioxide balance of a tropical peat swamp forest in Kalimantan, Indonesia. Global Change Biology 13: 412-425.

Kinasti, R.M.A. dan Notodisuryo, D.N. 2017. pemanfaatan limbah pembakaran batubara (bottom ash) pada pltu suralaya sebagai media tanam dalam upaya mengurangi pencemaran lingkungan. Jurnal Kajian Ilmu dan Teknologi 6: 81-162.

Kurniawan, A.R., Surono, W. dan Alimano, M. 2018. Potensi pemanfaatan limbah pembakaran batubara (bottom ash) pada PLTU sebagai media tanam dalam upaya mengurangi pencemaran lingkungan. Kilat 7(1): 36-46, doi: 10.33322/kilat.v7i1.97.

Masganti, M., Anwar, K. dan Susanti, M.A. 2020. Potensi dan pemanfaatan lahan gambut dangkal untuk pertanian. Jurnal Sumberdaya Lahan 11(1): 43-48, doi: 10.21082/jsdl.v11n1.2017.43-52.

Melling, L., Yun, T.C.S., Goh, K.J. and Hatano, R. 2013. Soil microbial and root respirations from three ecosystems in tropical peatland of Sarawak, Malaysia. Journal of Oil Palm Research 25:44-57.
Mulyani, A., Nursyamsi, D. dan Syakir, M. 2020. Strategi Pemanfaatan sumberdaya lahan untuk pencapaian swasembada beras berkelanjutan. Jurnal Sumberdaya Lahan 11(1): 11-22, doi: 10.21082/jsdl.v11n1.2017.11-22.

Nawaz, I. 2013. Disposal and utilization of fly ash to protect the environment. International Journal of Innovative Research in Science, Engineering and Technology 2(10): 5259-5266.

Nirmala, W., Pramiati, P. dan Dwi, I. 2020. Pengaruh Komposisi Sampah Pasar Terhadap Kualitas Kompos Organik Dengan Metode Larva Black Soldier Fly (BSF). Prosiding Seminar Nasional Pakar Ke 3 Tahun 2020, 1-5.

Noviardi, R. 2013. Limbah Batubara Sebagai Pembenah Tanah dan Sumber Nutrisi: Studi Kasus Tanaman Bunga Matahari (Helianthus annuиs). Jurnal Riset Geologi dan Pertambangan 23(1): 67-72. Doi: 10.14203/risetgeotam2013.v23.70.

Oktafiansyah, M.A.A., Lagowa, M. I. dan Tampubolon, G. 2020. Kajian teknis dan ekonomis pengaruh jenis kapur dalam upaya pengelolaan air asam tambang pertambangan (AAT). Jurnal Teknik Kebumian 5(2): 29-36.

Oktaviana, M. dan Nelvia. 2012. Pengaruh Pemberian Amelioran Dregs pada Tanah Gambut terhadap Pertumbuhan dan Akumulasi Logam Berat (Pb, Cr, Se, Ni) dalam Beras. Agrotechnology Departement, Agriculture Faculty, University of Riau. 9 hal.

Page, S.E., Siegert, F. Rieley, J.O., Boehm, H.D.V., Jaya, A. and Limin, S. 2002. The amount of carbon released from peat and forest fires in Indonesia during 1997. Nature 420(6911): 61 -65, doi: 10.1038/nature01131.

Priatmadi, B.J. Saidy, A.R. dan Septiana, M. 2012. Pengaruh abu batubara terhadap perbaikan sifat kimia tanah di Kalimantan Selatan. Buana Sains 14(2): 1-6.

Syahputra, E., Fauzi, dan Razali. 2015. Karakteristik sifat kimia sub grup tanah Ultisol di beberapa wilayah Sumatera Utara. Jurnal Agroekoteknologi 4(572): 1796-1803.

Yondra, dan Nelvia, W. 2017. Kajian sifat kimia lahan gambut pada berbagai landuse. Jurnal Agric 29(2): 103-112. 